\title{
Water Resources Management and Wastewater Treatment in the Democratic Republic of Congo (D.R.C): Application of Galvanic Treatment, Results and Prospectives
}

\author{
Arthur Kaniki Tshamala, ${ }^{1,2}$, Mathieu Kayembe Musala ${ }^{2,3}{ }^{*}$, Gigi Kasongo Kalenga1,2 \\ ${ }^{1}$ Department of Industrial Chemistry, Polytechnic Faculty, University of Lubumbashi, Lubumbashi, D.R. Congo \\ ${ }^{2}$ Laboratory of Environmental Analysis, Polytechnic Faculty, University of Lubumbashi, D.R. Congo \\ ${ }^{3}$ Department of Process Engineering, School of Industrial Engineering, University of Lubumbashi, Lubumbashi, D.R. Congo \\ Email: kaniki.tshamala@polytechunilu.ac.cd, *musala.kayembe@gmail.com, kalengagigi@yahoo.fr
}

How to cite this paper: Tshamala, A.K., Musala, M.K. and Kalenga, G.K. (2021) Water Resources Management and Wastewater Treatment in the Democratic Republic of Congo (D.R.C): Application of Galvanic Treatment, Results and Prospectives. Journal of Water Resource and Protection, 13, 190-197.

https://doi.org/10.4236/jwarp.2021.133011

Received: January 4, 2021

Accepted: March 7, 2021

Published: March 10, 2021

Copyright $\odot 2021$ by author(s) and Scientific Research Publishing Inc. This work is licensed under the Creative Commons Attribution International License (CC BY 4.0).

http://creativecommons.org/licenses/by/4.0/ (c) (i) Open Access

\begin{abstract}
The rapid industrial development and population growth increase the utilization of fresh water resulting in an increase of the amount of wastewater. Several Countries face a double challenge with regard to water resources, namely meeting the growing need for water for the population and treating the wastewater generated for application. The toxicity found in these water streams threatens the environment and human health. Hence the urgent need is to treat wastewater. The DRC is not immune from this threat. Its average population growth rate has exceeded the $3 \%$ and the number of industries it hosts continues to increase. The wastewater generated by this increasing pressure from urbanization and industrialization must be treated as required in the Congolese legal arsenal. Various factors need to be considered prior choosing the water treatment method. The choice must take into account the imperatives of the moment which are: modernization (local context) and sustainable development (international context). There are several wastewater treatments that are widely used for the removal of toxic elements such as ion exchange, reverse osmosis, chemical precipitation and electro-coagulation just to name a few. The most recent studies have shown that the galvanic technique can be used in the purification of water from domestic and industrial origin to meet drinking water standards. Various researchers have used this technique at laboratory and pilot scale demonstrating its cost-effectiveness as it uses no chemical reagents, consumes less energy and occupies only a small space for processing large flows. However, there are very few studies demonstrating the success of this treatment on an industrial scale. Therefore,
\end{abstract}


this work seeks to understand and master the mechanisms that take place in the galvanic treatment. In addition, this study focuses on the development of a robust prototype that is adaptable to the needs of various users while at the same time being relatively cheap to meet the national needs.

\section{Keywords}

Water Resources, Wastewater, Management, Galvanic Treatment

\section{Introduction}

The importance of water for life is well established. Water is both a living environment for the aquatic system, a drink for living beings and a raw material for industry. There is evidence that water in a liquid state only exists on planet earth. Some research endeavors to feature the presence of liquid water on different planets. It is assessed that in the event that liquid water is found on another planet, at that point the earth may not be the lone planet to hold life [1].

The world water supply is estimated to be $1,386,000,000 \mathrm{~km}^{3}$ and is found in three forms: Surface water, atmospheric and groundwater water. Surface water is the most accessible and consists of rivers, seas and dams and accounts for only around $1 \%$. They contain suspended solids; they are cloudy and difficult to settle. They are therefore not directly suitable for most common usages. They must therefore go through various steps of water treatment processes prior usage. Groundwater accounts for approximately $23 \%$ of all water reserves; they are not cloudy and generally do not contain microbes. They are clear, odorless and contain mineral salts. They are therefore suitable for most common usages. In the third and last form we find atmospheric waters (rain, dew, snow). They contain dust and dissolved gases, and do not contain the mineral salts necessary for living organisms [2].

Water is utilized for three main usages: domestic usages, agricultural usages and industrial usages. The average amount of water used per day per capita reflects the way of life for the population and the level of development of the country. In the US, the average population uses around 300 liters of water per day per capita. In Europe, the average is about 140 liters of water per day per capita. In Africa, statistics show that people use less than 20 liters of water per day per capita.

In the D.R.C., despite the importance of the water heritage, the rate of access to quality water is still very low. It is estimated that only about $28 \%$ of households have access to this water (with large disparities). In rural areas and on the outskirts of large cities, it is only $17 \%$. These data show that the D.R.C. has a lower rate of access to drinking water than many countries in its sub region. According to the World Bank, 77\% of people in Congo Brazzaville have access to improved sources of drinking water. This rate is $93 \%$ in Gabon, $76 \%$ in Cameroon, $76 \%$ in Rwanda and 69\% in Central Africa. This position is unacceptable if 
we know that thousands of cubic meters of water are pumped out of mines and sometimes simply discharged into the natural environment [1].

The objective of this article is to present the galvanic treatment of industrial wastewater and to show how this technique can be developed to treat wastewater loaded with heavy metals and suspended matter.

\section{Overview on Wastewater Treatment Processes}

Wastewater treatment processes fall into four categories: mechanical, physical, chemical and biological.

The essential operations relating to mechanical processes are screening, sand removal, sieving, filtration, centrifugation and oil removing [3] [4] [5].

The physical processes used to separate molecules or ionic species from their liquid or gaseous environment using various techniques such as decantation, flotation, degassing (stripping), adsorption, liquid-liquid extraction and filtration on membrane. These separation techniques are unit operations of process engineering and generally do not involve chemical reactions [6] [7] [8] [9].

The chemical processes allow the separation by involving surface or volume reactions. We can name the coagulation-flocculation, the neutralization, the redox and the ion exchange [2] [5].

The biological purification applies to oxidizable compounds which, in solution or in suspension, often constitute the major fraction of water pollution. Biodegradable oxidizable materials are those which can be eliminated by micro-organisms (bacteria) for which they serve as food. They are ultimately transformed into cellular constituents and into dissolved or solid gaseous waste [10].

Each of these techniques corresponds to a niche of use, a category of effluents to be treated and a very specific level of solute concentration.

\section{Galvanic Treatment of Water}

Galvanic or Electrocoagulation (EC) treatment is a treatment technique developed before the $20^{\text {th }}$ century [11]. The first document reporting the use of electrocoagulation for the treatment of effluents is an American patent filed in 1880 by WEBSTER [11] which used iron electrodes. In 1909, HARRIES files a new patent on this process [12] [13] [14]. The anodes were then made up of iron and aluminum plates. In 1980, numerous works were presented by Russian researchers on electrocoagulation as a means of efficient treatment of wastewater. Finally, in 1984, VIK carried out substantial work demonstrating the possibility of producing drinking water by the electrocoagulation process from Norwegian natural waters heavily loaded with humic substances [12] [15] [16]. Despite this extensive research, the electrocoagulation process has declined significantly due to the development of other water treatment processes which, at the time, appeared to be simpler and less expensive. The call for the development of clean water treatment processes and the development of analytical means have enabled electrocoagulation to gain importance, thus offering a competitive investment and treatment cost, and a large elimination efficiency of pollutants. 
The electrocoagulation process is based on the electrochemical dissolution of a sacrificial metal which, once in the effluent and through other related reactions such as the electrolysis of water, gives complexes of metal hydroxides which will ensure adsorption and flocculation of particles and dissolved pollutants [11] [17] [18].

This involves imposing a current (or potential) between two electrodes immersed in an electrolyte contained in a reactor to generate, in situ, ions, capable of causing coagulation-flocculation of the pollutants which it is desired to eliminate [13] [19] [20]. The electrolysis can also coagulate the oxidizable or reducible soluble compounds contained in the effluent. The electric field creates a movement of charged ions and particles. This action makes it possible to collect the suspended materials in the form of flocs which are then eliminated by a conventional physical process (decantation, flotation, filtration, etc.). Figure 1 shows the principle diagram of electrocoagulation.

\section{Materials and Methods}

\subsection{Description of the Drinkwell IFC-120}

The tests were carried out using the Drinkwell IFC-120 device, a prototype made in Australia. It consists of a Plexiglas container of parallelepiped shape divided into 4 cells in which the electrodes are housed. Its length is $98 \mathrm{~cm}$, the width of $37.5 \mathrm{~cm}$ and its height of $40 \mathrm{~cm}$; which gives it a theoretical capacity of 160 liters. Its electrodes consist of stacked sheets, alternating between anode and cathode, 1 $\mathrm{cm}$ apart between the anode and the cathode. Three types of electrodes are used: Iron electrode, aluminum electrode and copper electrode. The different cells are connected to each other by locks which make the whole a system of communicating vessels. The device includes a box in which the various electronic and electrical components of the device are mounted (Electronics control box). All orders are made from this control box which is provided with two ammeters for reading the current intensities in the first and second cell. The water to be treated is supplied to the machine using a small diaphragm pump with an engine power of $0.38 \mathrm{~kW}$, giving a maximum flow rate of 40 liters per minute and a maximum delivery head of 38 meters. The raw water is supplied to the first cell and passes from cell to cell by overflow. The flow of water to the feed is regulated using a valve located just at the inlet of the first cell. The supply valve is fitted with a non-return valve to prevent the return of water if the pump stops.

\subsection{Analytical Methods}

The quantitative chemical analyzes were carried out by Atomic Absorption Spectrometry on the Analytik Jena AG nov AA 400 spectrometer. This device is calibrated using standard solutions and makes it possible to quantitatively measure major, minor as well as trace metal elements with a detection limit of 0.0001 $\mathrm{mg} / \mathrm{L}$. The S.S were measured using the Wagtech WT3020 turbidimeter and the $\mathrm{DR} / 890$ colorimeter. 


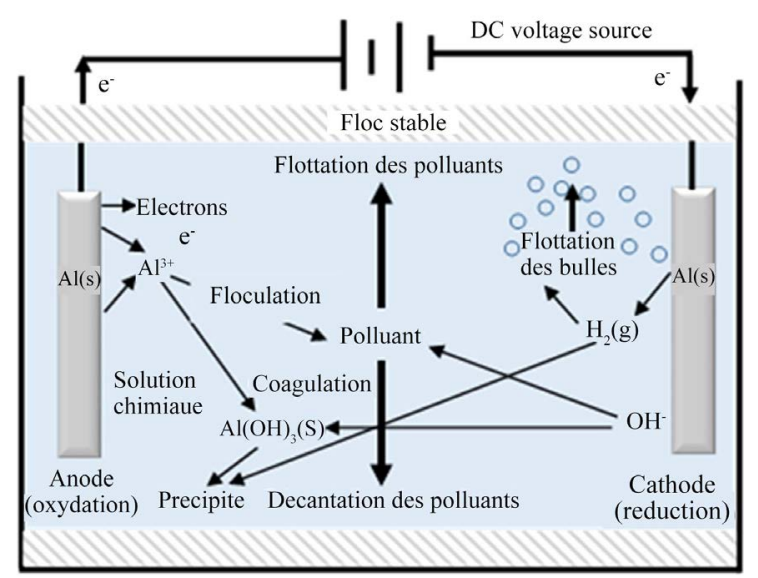

Figure 1. Schematic diagram of the galvanic treatment of water.

\section{Results}

\subsection{Results of the Characterization of the Sample}

The treated sample consists of the industrial liquid effluent from a metallurgical plant in Lubumbashi, the physicochemical characteristics and chemical composition of which are given in the Table 1.

The results in Table 1 indicate that the effluent from the plant is loaded with dissolved metals and suspended solids (S.S or MES). The permissible concentration of these metallic elements in the effluent must be below $1 \mathrm{mg} / \mathrm{L}$ prior discharge into the environment, while the concentration of S.S must not exceed the threshold of $100 \mathrm{mg} / \mathrm{L}$.

\subsection{Evolution of the Concentration of Metals in the Different Cells}

Table 2 shows the trend in concentration of metals in the different cells over time during the galvanic treatment. The samples were taken in each cell at 5, 20 and $40 \mathrm{~min}$.

The results show respectively that $\mathrm{Fe}, \mathrm{Cu}, \mathrm{Co}, \mathrm{Zn}, \mathrm{Pb}$ and suspended solid concentration decreases over time in the different cells.

The determination of the optimum treatment time involves monitoring the evolution over time of the purification rate for each parameter studied. The purification rate is a ratio which makes it possible to evaluate the effectiveness of the treatment in relation to a given parameter and is given by the following expression:

$$
\text { T.E. }=\frac{\text { concentration at the alimentation-concentration at the output of the device }}{\text { concentration feed }} \times 100 \% \text { (1) }
$$

Figure 2 gives the results of monitoring the evolution of the purification rate.

\section{Discussion}

The set of results shows that the large proportion of heavy metals and of S.S is recovered in the first two cells except for $\mathrm{Co}$ and $\mathrm{Pb}$ which record a relatively low recovery. This recovery can be attributed to several phenomena that take 
place in different cells such as adsorption phenomena, precipitation reactions, complexation and redox equilibria. These phenomena act alone or in synergy. It is possible to highlight the importance of each phenomenon from the study of speciation. These results indicate that it is possible, by varying parameters such as time, geometrical configuration of the device, hydrodynamics of the liquid flow and the nature of the electrodes, to improve the purification rates.

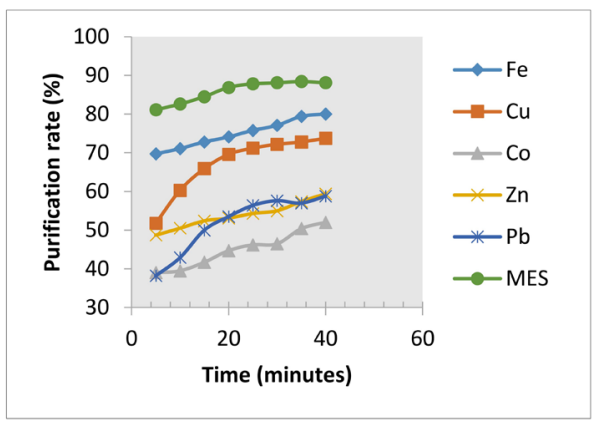

Figure 2. Evolution of purification rates over time.

Table 1. Results of the characterization of the sample.

\begin{tabular}{ccccccccc}
\hline \multirow{2}{*}{ Parameters } & \multicolumn{3}{c}{ Physico-chemical characteristics } & \multicolumn{4}{c}{ Chemical composition in $\mathrm{mg} / \mathrm{L}$} \\
\cline { 2 - 9 } & $\mathrm{pH}$ & $\mathrm{EC}^{*}(\mu \mathrm{S} / \mathrm{cm})$ & $\mathrm{SS}^{* *}(\mathrm{mg} / \mathrm{L})$ & $\mathrm{Fe}$ & $\mathrm{Co}$ & $\mathrm{Cu}$ & $\mathrm{Pb}$ & $\mathrm{Zn}$ \\
\hline Values & 8.9 & 40.800 & 1.000 & 15 & 7.4 & 3.2 & 1.7 & 17 \\
\hline
\end{tabular}

*EC: Electrical conductivity; **SS or ME: Suspended solid.

Table 2. Evolution of the concentration of metals in the different cells over time taken at $5,20 \& 40 \mathrm{~min}$.

\begin{tabular}{|c|c|c|c|c|c|}
\hline & \multirow{2}{*}{ Time $(\min )$} & Cell 1 & Cell 2 & Cell 3 & Cell 4 \\
\hline & & $\mathrm{mg} / \mathrm{L}$ & $\mathrm{mg} / \mathrm{L}$ & $\mathrm{mg} / \mathrm{L}$ & $\mathrm{mg} / \mathrm{L}$ \\
\hline \multirow{3}{*}{$\mathrm{Fe}$} & 5 & 8.27 & 6.23 & 4.88 & 4.54 \\
\hline & 20 & 6.87 & 5.65 & 4.62 & 3.88 \\
\hline & 40 & 5.22 & 4.97 & 3.87 & 2.99 \\
\hline \multirow{3}{*}{$\mathrm{Cu}$} & 5 & 2.28 & 2.24 & 2.17 & 1.54 \\
\hline & 20 & 2.17 & 1.97 & 1.94 & 0.97 \\
\hline & 40 & 1.69 & 1.49 & 1.64 & 0.84 \\
\hline \multirow{3}{*}{ Co } & 5 & 6.4 & 5.89 & 5.62 & 4.51 \\
\hline & 20 & 5.64 & 5.23 & 4.45 & 4.09 \\
\hline & 40 & 5.27 & 3.52 & 2.98 & 3.55 \\
\hline \multirow{3}{*}{$\mathrm{Zn}$} & 5 & 13.27 & 11.73 & 10.45 & 8.72 \\
\hline & 20 & 11.65 & 10.14 & 9.52 & 7.96 \\
\hline & 40 & 10.15 & 9.11 & 8.02 & 6.89 \\
\hline \multirow{3}{*}{$\mathrm{Pb}$} & 5 & 1.67 & 1.62 & 1.43 & 1.05 \\
\hline & 20 & 1.41 & 1.32 & 1.09 & 0.79 \\
\hline & 40 & 1.17 & 1.11 & 0.79 & 0.7 \\
\hline \multirow{3}{*}{ SS } & 5 & 357.45 & 368.88 & 225.67 & 188.43 \\
\hline & 20 & 345.64 & 297.64 & 167.82 & 130.61 \\
\hline & 40 & 198.76 & 177.46 & 130.42 & 118.49 \\
\hline
\end{tabular}


Up to $70 \%$ of suspended solids were removed in the first cell, after only five minutes of steady state operating conditions. The second cell also records similar treatment rates. Thereafter, a sudden drop is observed as the effluent proceeds into the $3^{\text {rd }}$ and $4^{\text {th }}$ cell which presages a function of settling of the third cell. The observation of the flocs formed in the second cell invites us to consider that there is coagulation in the first cell and flocculation in the second. In fact, the aluminum and iron released in solution can associate with hydroxide ions to form a coagulant.

The optimizing purification rate requires a thorough understanding of the mechanisms involved. This is the subject of ongoing studies. These studies attempt to model, using PhreeqC software, redox reactions, precipitation or dissolution of minerals in solution, complexation reactions as well as the interactions between the different phases. This work can therefore be deepened using thermodynamic calculation and chemical reaction modeling software.

\section{Conclusions}

The objective of this article was to present the galvanic treatment of industrial wastewater and to show how this technique can be developed to treat wastewater loaded with heavy metals and suspended solids.

The adopted methodology consisted in carrying out pilot treatment tests on an industrial wastewater sample with a Drinkwell ICF-120 brand prototype. The sample concerned is a metallurgical effluent loaded with $\mathrm{Fe}(15 \mathrm{mg} / \mathrm{L})$, Co $(7.4$ $\mathrm{mg} / \mathrm{L}), \mathrm{Cu}(3.2 \mathrm{mg} / \mathrm{L}), \mathrm{Pb}(1.7 \mathrm{mg} / \mathrm{L})$ and $\mathrm{Zn}(17 \mathrm{mg} / \mathrm{L})$.

The results obtained show that it is possible to treat industrial metallurgical effluents loaded with heavy metals and suspended matter until reaching purification rates of $80 \%, 74 \%, 52 \%, 60 \%, 59 \%$ and $88 \%$, for $\mathrm{Fe}, \mathrm{Cu}, \mathrm{Co}, \mathrm{Zn}, \mathrm{Pb}$ and S.S respectively. The increase in purification rates over time in different cells clearly shows the possibility of treating effluents to bring them back to the standards of discharge into the natural environment.

As we can see, this technique offers the advantage of being adaptable to the needs of different users, of being less expensive, of not using any chemical reagent, of consuming very little energy and of occupying only a small space to process large flows (up to 40 liters per minute). Galvanic treatment appears from this point of view as an innovative alternative in line with the needs of manufacturers and public authorities.

\section{Conflicts of Interest}

The authors declare no conflicts of interest regarding the publication of this paper.

\section{References}

[1] Kaniki, T.A. (2018) Eau, promotion du paysannat et apport du secteur minier: Enjeux et défis pour le Haut-Katanga. Inédit.

[2] Mouchet, P. (2005) Techniques de l'ingénieur: Traitements des eaux avant utilisation, 
Matières particulaires. 12 .

[3] Bensadok, K. (2007) Procédé de traitement d'émulsions huile/eau et eau/huile, cas particulier d'émulsion d'huile de coupe. Université des Sciences et de la Technologie Houari Boumediene, Algérie, 218.

[4] Pascal, P. and Dupont, G. (1965) Technique de l'ingénieur: Chimie et Génie chimique. 49.

[5] Koller, E. (2004) Traitement des pollutions industrielles eaux-air-déchets-sol-boue, Dunod.

[6] Hernandez De Leon, H.R. (2006) Supervision et diagnostic des procédés de production d'eau potable. Institut National des Sciences Appliquées de Toulouse, Spécialité: Systèmes Automatiques, 163.

[7] Camileri, C. (1980) Les techniques de flottation-Application à l'épuration des eaux usées industrielles et urbaines et à la préparation des eaux potables. La Tribune du CEBEDEAU, 33, 497-505.

[8] Berland, J.-M. and Juery, C. (2002) Procédés membranaires pour le traitement de l'eau. Document Technique FNDAE N $14,71 \mathrm{p}$. https://www.oieau.org/eaudoc/system/files/documents/37/185566/185566 doc.pdf

[9] Berset, C., Jaskiewicz, H., Sung, G.T.M. and Sandret, F. (2008) Méthodes électrolytiques d'épuration des eaux résiduaires; Elimination de surfactifs de synthèse. La Tribune du CEBEDEAU, 424, 79-88.

[10] Labanowski, J. (2004) Matière organique naturelle et anthropique: Vers une meilleure compréhension de sa réactivité et de sa caractérisation. Universite de Limoges, Faculté des Sciences et Techniques, Ecole Nationale Supérieure d'Ingénieurs de Limoges, $\mathrm{N}^{\circ}$ d'ordre: 36-2004, 209.

[11] Zongo, I. (2009) Etude expérimentale et théorique du procédé d'électrocoagulation: Application au traitement de deux effluents textiles et d'un effluent simulé de tannerie. Institut National Polytechnique de Lorraine, Spécialité: Génie des procédés et des produits, 226.

[12] Bennajah, M. (2007) Traitement des rejets industriels liquide par électrocoagulation/électroflottation en réacteur airlift. Institut National Polytechnique de Toulouse, Spécialité: Génie des procédés et de l'environnement, Nº d'ordre: 2558, 204.

[13] Zidane, F. (2006) Etude de l'épuration par électrocoagulation des rejets liquides d'une industrie de traitement de surface à Casablanca. Université de Casablanca, Inédit.

[14] Desjardins, R. (2007) Le traitement des eaux, $2^{\mathrm{è}}$ Edition revue et enrichie. Presse Internationale Polytechnique, Canada.

[15] Martin, G. (1982) Point sur l'épuration et le traitement des effluents. Eau-Air, Vol. Problèmes biologiques généraux, Technique et Documentation (1982).

[16] Gomelle, C. and Guerre, H. (1983) Les eaux usées dans les agglomérations urbaines ou rurales. Eyrolles, Paris.

[17] Rondia, D. (1998) Les métaux lourds et l'environnement. Electricité Nº 188, 3-20.

[18] Bechac, J.-P., Boutin, P., Mercier, B. and Nuer, P. (1987) Traitement des eaux usées. Ed. Eyrolles, Paris, 61.

[19] Riou, G. (1990) L'eau et les sols dans les géosystèmes tropicaux, Système d'érosion hydrique. Masson, Paris, 24.

[20] Degrémont (1989) Mémento technique de l'eau. 9e éd., 2 vol., Lavoisier, 18. 